\title{
Is subdiaphragmatic aortic cross-clamping a suitable model for spinal cord ischemia/reperfusion injury study in rats? ${ }^{1}$
}

\author{
O pinçamento sub-diagragmático da aorta é um modelo adequado para o estudo da \\ lesão medular de isquemia/reperfusão em ratos?
}

\author{
Sonia Elizabeth Lopez Carrillo², Sérgio Botelho Guimarães ${ }^{3}$, Paulo Roberto Cavalcante de Vasconcelos ${ }^{4}$, Paulo Roberto \\ Leitão de Vasconcelos ${ }^{5}$ \\ 1. Experimental Surgical Research Laboratory, Department of Surgery, Post-Graduation Program, Federal University of Ceará (UFC), Brazil. \\ 2. Vascular Surgeon, Mossoró, Brazil. \\ 3. Associate Professor of Surgery, Department of Surgery, UFC, Brazil. \\ 4. Medical student, UFC, Brazil. \\ 5. Associate Professor of Surgery, Coordinator of Post-Graduation Program, Faculty of Medicine, UFC, Brazil.
}

\begin{abstract}
Purpose: To evaluate the efficacy of subdiaphragmatic aortic cross-clamping in an experimental model of ischemia/ reperfusion injury of the spinal cord in albino rats. Methods: Thirty-six male Wistar rats were randomized in two groups (n=18): G-1 (Sham) and G-2 (Ischemia/Reperfusion, I/R). G-2 rats were submitted to 30 min subdiafragmatic aortic crossclamping. G-1 rats served as controls and were submitted to surgical trauma (laparotomy) without ischemia. Samples (spinal cord and arterial blood) were collected at the end of ischemic period and 10 (T-10) and 20 (T-20) min later in G-2 rats. Sham rats (G-1) samples were collected at the same time-points. Blood and tissue metabolites concentrations of pyruvate, lactate, glucose and medullary adenosine triphosphate (ATP) were assayed. Results: Blood and tissue concentrations of pyruvate and glucose as well as lactate and medullary ATP were not different when comparing G1 to G2. Lactacemia was significantly elevated in G-2 compared with G-1 rats during reperfusion (T-10). Conclusion: Subdiaphragmatic aortic cord cross-clamping is not a suitable rat model for spinal cord ischemia/reperfusion injury study as it does not ensure changes in in vivo tissue metabolites concentrations similar to those found in tissues subjected to ischemia/reperfusion.
\end{abstract}

Key words: Ischemia. Reperfusion Injury. Spinal Cord. Models, Animal. Rats.

\section{RESUMO}

Objetivo: Avaliar a eficácia do pinçamento da aorta subdiafragmática no modelo experimental de isquemia/reperfusão da medula espinhal em ratos. Métodos: Trinta e seis ratos Wistar, machos, foram aleatoriamente distribuídos em 2 grupos $(n=18)$ e submetidos ao pinçamento subdiafragmático da aorta, durante 30 minutos (Grupo-2 -Isquemia/Reperfusão). Os ratos do Grupo-1 (G-1 - Sham) foram utilizados como controles e submetidos a laparotomia sem pinçamento arterial. As amostras (medula e sangue arterial) foram coletadas ao término do período de isquemia (T-0) e 10 (T-10) e 20 (T-20) minutos mais tarde e nos mesmos intervalos, no grupo G-1. As concentrações teciduais e sanguíneas de piruvato, lactato, glicose e as concentrações medulares de trifosfato de adenosina (ATP) foram determinadas por ensaios enzimáticos. Resultados: As concentrações de piruvato e glicose (sangue e tecido) e de lactato e ATP (medula) não foram diferentes,comparando G1 versus G-2. A lactacemia elevou-se significantemente no G-2, comparado ao G-1, durante a reperfusão (T-10). Conclusão: O modelo experimental de pinçamento subdiafragmático da aorta não é adequado para o estudo da lesão de isquemia/ reperfusão na medula de ratos, uma vez que não proporciona alterações nas concentrações in vivo de metabólitos teciduais, por exemplo de lactato ou ATP, compatíveis com aquelas encontradas em tecidos sujeitos à isquemia/reperfusão. Descritores: Isquemia. Traumatismo por Reperfusão. Medula Espinhal. Modelos Animais. Ratos.

\section{Introduction}

Temporary interruption of spinal cord blood supply may result in irreversible ischemic injury and neurological deficits. Surgical repair of some arterial diseases including thoracoabdominal aortic aneurysm is a challenging task to the surgeon's technical skills. Devastating complications may take place during the surgical procedure, leading to paraplegia, renal failure or cardiac arrest and death ${ }^{1}$.
Fortunately, infra-renal aortic cross-clamping is not frequently accompanied by paraplegia in humans due the blood supply provided by the greater radial artery (formerly known as Adamkiewicz artery) ${ }^{2}$. There is an urgent need to develop new surgical techniques and drugs aimed at reducing operating time and increasing the tolerable duration of ischemia as a priority in medical research ${ }^{3}$.

Experimental models of spinal cord ischemia have been developed in many animals, including $\operatorname{dog}^{4}$, rabbit ${ }^{5}$, baboon 
${ }^{6}$, pig ${ }^{7}$, and rat ${ }^{8}$. In these models thoracic or abdominal aorta is cross-clamped, causing significant but incomplete reduction in spinal cord blood flow ${ }^{9}$. Schievink et al. ${ }^{10}$ studied the arterial supply of the spinal cord of the Wistar rat and did not observe a single large artery at the thoracolumbar level supplying a large part of the spinal cord. They concluded that the equivalent of the greater radial artery is not invariably present in the rat; therefore, the vascular anatomy of the rat spinal cord is not as similar to that of man as it has previously been reported ${ }^{10}$. The aim of the study was to evaluate the efficacy of subdiaphragmatic aortic cross-clamping in a model of ischemia/reperfusion injury of the spinal cord in Wistar rats, as judged by changes in in vivo concentrations of metabolites in spinal cord tissue and in blood.

\section{Methods}

Thirty-six male albino Wistar (Mammalia Rodentia, Muridae, Rattus Norvegicus Albinus) rats obtained from Faculty of Medicine (Federal University of Ceará) Small Animals Laboratory weighing 300-350 g (average 330 g) were used in this study. All animals were of the same breed and were raised in controlled environment for research use only. The study was conducted in compliance with the guidelines of the Council for International Organization of Medical Sciences (CIOMS) ethical code for animal experimentation ${ }^{11}$ and the rules on animal breeding and use in studies and research set forth by Colégio Brasileiro de Experimentação Animal (COBEA). ${ }^{12}$ Rats were subjected to a standard $12 \mathrm{~h}$ light-dark cycle (6:00 AM to 6:00 PM) and room temperature was maintained at $25^{\circ} \mathrm{C}$. All animals were housed in polypropylene cages in groups of 5 rats and allowed free access to food and water. Rats were randomized in 2 groups $(\mathrm{n}=18)$. Additionally, each group was distributed in 3 subgroups (T-0, T-10 and T-20). G-2 rats were submitted to 30 min subdiafragmatic aortic crossclamping. G-1 rats served as controls and were submitted to surgical trauma (laparotomy) without ischemia. Samples (spinal cord and arterial blood) were collected at the end of ischemic period (T-0) and 10 (T-10) and 20 (T-20) min later in $\mathrm{G}-2$ rats. Sham rats (G-1) samples were collected at the same time-points, starting collection of samples $30 \mathrm{~min}$ after laparotomy. All surgical procedures were performed under inhalatory diethyl ether anesthesia. Following sample harvesting all animals were killed under general inhalatory anesthesia. Enzymatic analysis was used for tissue and blood determinations of metabolites (glucose, pyruvate, lactate, and ATP according to biochemical methods published elsewhere. ${ }^{13-15}$ Values are expressed as mean \pm S.E.M. Student's t test or nonparametric MannWhitney U-test as appropriate were used to analyze the significance of the differences between control and experimental groups. Kruskal-Wallis test (with Dunn's post test) was used for multiple comparisons.

\section{Results}

Tissue concentrations of lactate (Figure 2), glucose (Figure 3) and ATP (Figure 4) and blood concentrations of pyruvate (Figure 5) and glucose (Figure 6) were not different comparing G1 to G2. Spinal cord pyruvate concentration (Figure 1) dropped significantly during reperfusion (T-20) in G-2 rats. Lactacemia (Figure 7) was significantly elevated in ischemic rats (G-2) compared with sham-operated rats at T-10 time-point.

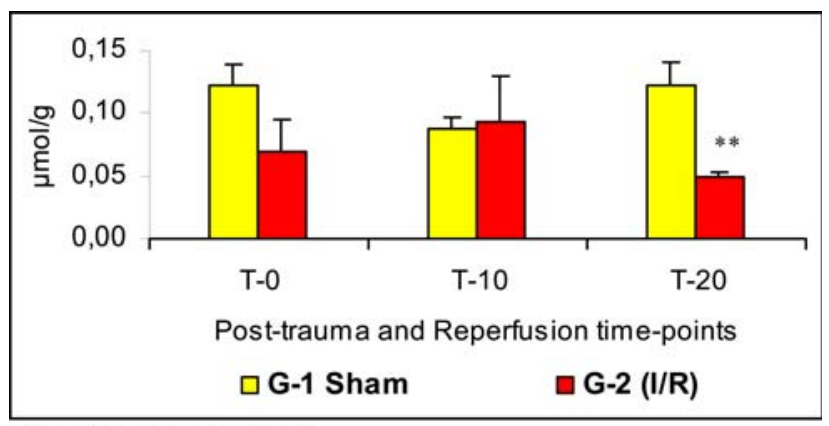

** $p<0.01$ compared with $\mathrm{G}-1$

FIGURE 1 - Spinal cord pyruvate concentrations $(n=6)$ in G-1 and G-2 groups tissue homogenates. Values are expressed as mean \pm S.E.M.

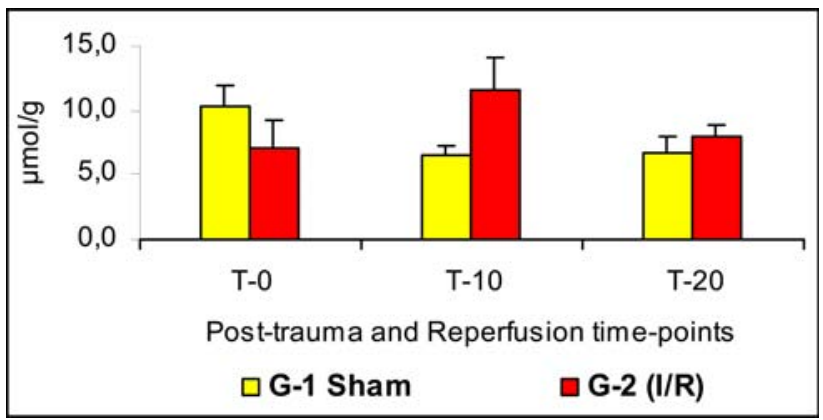

FIGURE 2 - Spinal cord lactate concentrations ( $n=6)$ in $\mathrm{G}-1$ and $\mathrm{G}-2$ groups tissue homogenates. Values are expressed as mean \pm S.E.M.

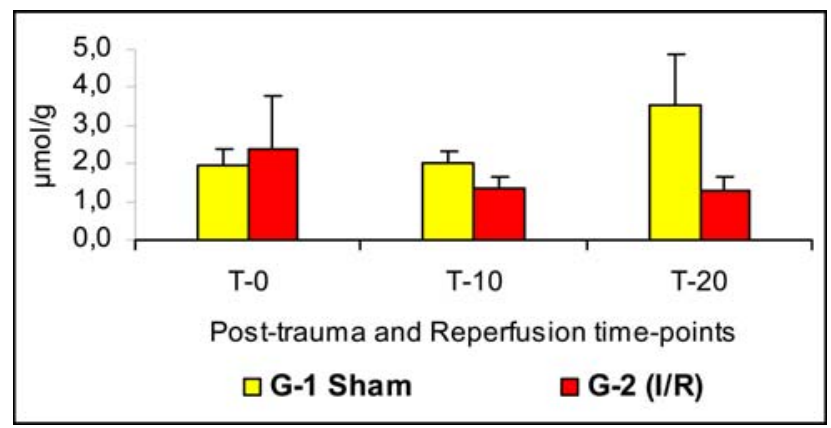

FIGURE 3 - Spinal cord glucose concentrations (n=6) in G1 and G-2 groups tissue homogenates. Values are expressed as mean \pm S.E.M. 


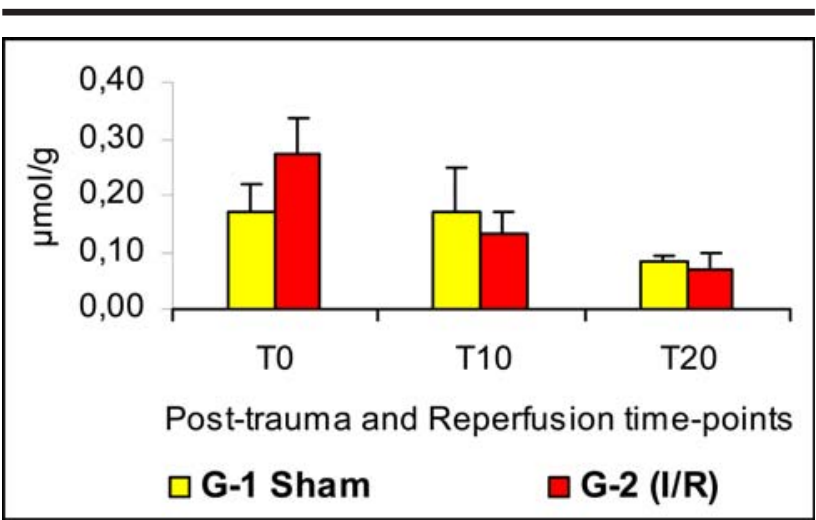

FIGURE 4 - Spinal cord ATP concentrations ( $n=6)$ in $G-1$ and G-2 groups tissue homogenates. Values are expressed as mean \pm S.E.M.

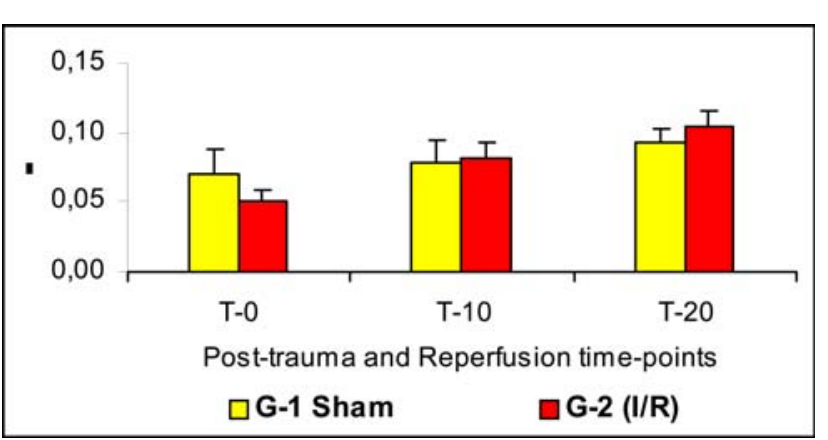

FIGURE 5 - Blood pyruvate concentrations $(n=6)$ in $\mathrm{G}-1$ and G-2 rats. Values are expressed as mean \pm S.E.M.

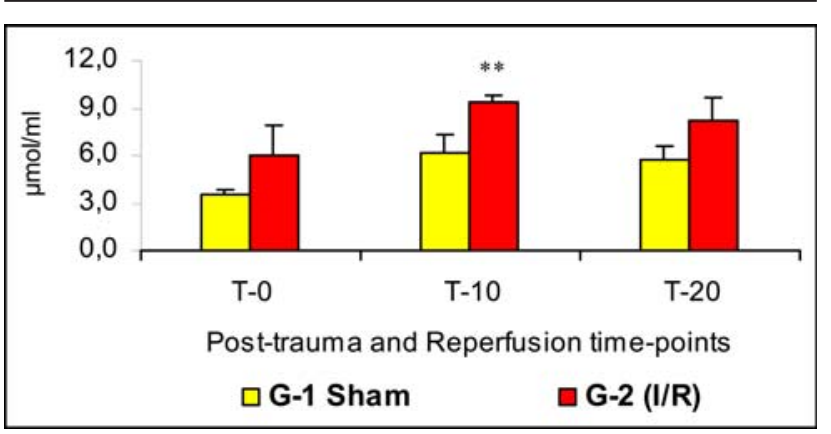

FIGURE 6 - Blood glucose concentrations ( $n=6$ ) in G-1 and $\mathrm{G}-2$ rats. Values are expressed as mean \pm S.E.M.

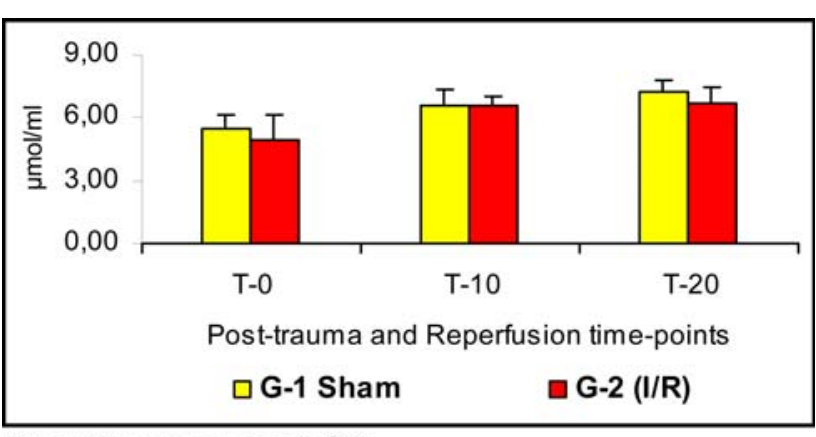

** $p<0.01$ compared with $\mathrm{G}-1$

FIGURE 7 - Blood lactate concentrations (n=6) in G-1 and G-2 rats. Values are expressed as mean \pm S.E.M.

\section{Discussion}

Acute hypoxic tissue injury has been studied in a variety of rat tissues ${ }^{16-20}$. When a tissue is deprived of its oxygen supply, the mitochondrial electron transportoxidative phosphorylation sequence is inhibited resulting in decline of cellular levels of ATP and creatine phosphate. As cellular ATP levels diminish, anaerobic glycolysis is activated in an attempt to maintain normal cellular functions. Glycogen levels are rapidly depleted and lactic acid in cytosol increases, reducing intracellular $\mathrm{pH}^{21}$. The absence of significant differences in spinal cord concentrations of pyruvate lactate, glucose and ATP suggests that there was no effective spinal cord ischemia in this experimental model. The increase in lactacemia during reperfusion (T-10) in rats subjected to aortic cross-clamping could be explained to release of lactate into the blood stream after aortic clamp removal. As lactate production within the cells results from anaerobic glycolysis, with conversion of pyruvate to lactate when oxygen supply is not adequate, the increase in lactacemia could be related to a certain degree of tissue ischemia, in organs and tissues, other than the spinal cord, such as kidneys and limb muscles, that have suffered reperfusion lesion due to aortic arterial clamping .

\section{Conclusion}

Subdiaphragmatic aortic cord cross-clamping is not a suitable rat model for spinal cord ischemia/reperfusion injury study as it does not ensure complete spinal cord ischemia or changes in in vivo tissue metabolites concentrations, for example lactate and ATP, similar to those found in tissues subjected to ischemia/reperfusion.

\section{References}

1. Gloviczki P. Surgical repair of thoracoabdominal aneurysms: patient selection, techniques and results. Cardiovasc Surg. 2002;10(4):434-41.

2. Lang-Lazdunski L, Matsushita K, Hirt L, Waeber C, JeanPaul G. Vonsattel J-PG, Moskowitz MA. Spinal cord ischemia: development of a model in the mouse. Stroke. 2000;31:208-13.

3. Reyes O, Sosa I, Kuffler DP. Neuroprotection of spinal neurons against blunt trauma and ischemia. P R Health Sci J. 2003; 22(3):277-86.

4. Negrin J Jr. The hypothermostat: an instrument to obtain local hypothermia of the brain or spinal cord. Int Surg. 1970; 54:93-106.

5. Zivin JA, DeGirolami U. Spinal cord infarction: a highly reproducible stroke model. Stroke. 1980; 11:200-2

6. Svensson LG, Hunter SJ, Von Ritter CM, Robinson MF, Groeneveld HT, Hinder RA, Rickards ES. Cross-clamping of the thoracic aorta. Ann Surg. 1986; 204:38-47.

7. Salzano RP, Ellison LH, Altonji PF, Richter J, Deckers PJ. Regional deep hypothermia of the spinal cord protects against ischemic injury during thoracic aortic crossclamping. Ann Thorac Surg. 1994; 57:65-71.

8. LeMay DR, Lu AC, Zelenock GB, D’Alecy LG. Insulin 
administration protects from paraplegia in the rat aortic occlusion model. J Surg Res. 1988; 44:352-8.

9. Taira Y, Marsala M. Effect of proximal arterial perfusion pressure on function, spinal cord blood low and histopathologic changes after increasing intervals of aortic occlusion in the rat. Stroke. 1996;27:1850-8.

10. Schievink WI, Luyendijk W, Los JA. Does the artery of Adamkiewicz exist in the albino rat? J Anat. 1988;161:95-101.

11. Council for International Organization of Medical Sciences (CIOMS). Ethical code for animal experimentation. WHO Chronicle. 1985; 39(2):51-6.

12. Princípios éticos na experimentação animal, Colégio Brasileiro de Experimentação Animal/Cobea;1991. Disponível em http://www.cobea.org.br/etica.htm\#3

13. Slein MW. Determination with hexokinase and glucose6-phosphate dehydrogenase. In: Bergmeyer HU. Methods of enzymatic analysis. London: Verlag Chemie, Weinheim/Academic Press; 1963. p.117-23.

14. Hohorst HJ. D-Glucose-6-phosphate and D-fructose-6phosphate. etermination with glucose-6-phosphate dehydrogenase and phosphoglucose isomerase. In: Bergmeyer HU (editor). Methods of enzymatic analysis. London: Verlag Chemie, Weinheim/Academic Press; 1963. p.134-8.

15. Lamprecht W, Trautschold I. Determination with hexokinase and glucose-6-phosphate dehydrogenase. In: Bergmeyer HU (editor). Methods of enzymatic analysis. London: Verlag Chemie, Weinheim/Academic
Press; 1963. p.543-1.

16. Guimarães SB, Vasconcelos PRL. In vivo acute changes in ATP and glucose concentrations in the testicles of prepubertal rats following unilateral torsion. Acta Cir Bras. 2002;17(2):110-5.

17. Bezerra Filho JE, Guimarães SB, Chaves CR, Queiroz DAF, Vasconcelos PRC, Vasconcelos PRL. Effects of L-alanylglutamine on in vivo kidney and blood concentrations of glucose, pyruvate and lactate in rats subjected to unilateral renal ischemia and reperfusion. Rev Bras Nutr Clin. 2002;17(4):122-5.

18. Torres JMS, Guimarães SB, Martins MCR,Chaves, CR, Vasconcelos PRL. Efeitos metabólicos da l-alanilglutamina em ratos submetidos à isquemia da pata traseira esquerda seguida de reperfusão. Acta Cir Bras. 2003;18(18): 39-44.

19. Guimarães Filho A, Guimarães SB, Vasconcelos PRC, Vasconcelos PRL. Efeitos metabólicos da oferta endovenosa de L-alanil-glutamina no sangue e fígado de ratos submetidos a hepatectomia parcial. Rev Bras Nutr Clin. 2004;19(2):54-8.

20. Alves MA, Guimarães SB, Dias DA, Vasconcelos PRC, Coelho VPM, Vasconcelos PRL. Effects of L-alanylglutamine upon the blood and kidney biochemical parameters in the rat hind limb model of ischemia/ reperfusion. Acta Cir Bras. 2003;18(3): 445-9.

21. Olson MO. Oxidative phosphorylation. In: Devlin TM (editor). Textbook of biochemistry with clinical correlations. New York: Wiley-Liss; 1997. p.261-3.

\section{Correspondence:}

Prof. Paulo Roberto Leitão de Vasconcelos

Department of Surgery

Rua Prof. Costa Mendes, 1608/3 andar

60430-140 Fortaleza-CE Brazil

Phone: (55 85)4009-8063

Fax: (5585)4009-8062

mcirur@npd.ufc.br
Conflict of interest: none Financial source: none

Received: January 10, 2006

Review: February 18, 2006

Accepted: March 21, 2006

\section{How to cite this article:}

Carrillo SEL, Guimarães SB, Vasconcelos PRC, Vasconcelos PRL. Is subdiaphragmatic aortic cross-clamping a suitable experimental model for spinal cord ischemia/reperfusion injury study in rats? Acta Cir Bras. [serial on the Internet] 2006 July-Aug;21(4). Available from URL: http://www.scielo.br/acb 